\title{
SUSTAINABLE EFFICIENCIES IN SMALL SCALE CASSAVA FARMERS IN ORUK ANAM LOCAL GOVERNMENT AREA OF AKWA IBOM STATE, NIGERIA
}

\author{
*Akpan, S. B., Udo, U. J., and Okon, U. E. \\ Department of Agricultural Economics and Extension, \\ Akwa Ibom State University, Obio Akpa Campus, Akwa Ibom State, Nigeria \\ ${ }^{*}$ Corresponding Author: sundayakpan@aksu.com.
}

\begin{abstract}
This study derived sustainable technical, economic and allocative efficiencies from a set of efficiencies generated from the maximum likelihood estimation of stochastic production and profit functions fitted with data collected from small scale cassava farmers. The study was conducted in Oruk Anam Local Government Area of Akwa Ibom State, Nigeria. A three-stage sampling method was employed to select choose respondents' to which structured questionnaire was administered to obtain the necessary information for the study. The result revealed an average sustainable technical efficiency of $81.60 \%, 30.40 \%$ for profit efficiency and $38.40 \%$ for allocative efficiency. Results further showed that farming experience, membership in social organization, years of formal education, farm capital and farm size were the positive determinants of sustainable technical efficiency while household size, number of female cultivating cassava, poor farming households and the use of organic manure were negative. In the same Vein, farming experience, education farm size, gender and the use of tillage technology were identified as positive determinants of sustainable economic or profit efficiency while household size and quantity of fertilizer use had negative impacts. Similarly, cassava farmers' farm size, age, educational level, farming experience, gender and the use of tillage technology impacted positively on sustainable allocative efficiency while household size and the quantity of fertilizer have negative relationships. In order to achieve sustainability of small scale cassava farms, it is recommended that social capital formation should be intensified among cassava farmers. Also, adult education and family planning programmes for farmers should be fine-tuned in the state for effective delivery among others.
\end{abstract}

Keywords: Cassava, Technical efficiency, economic efficiency, allocative efficiency, sustainability. 


\section{INTRODUCTION}

Cassava (Manihot esculenta Crantz) is a popular food crop in most parts of Nigeria with expanding acceptability (Adeyemo et al., 2010) and a wide range of derivatives (Akpan et al., 2014). In Nigeria, the crop is widely cultivated by resource-poor small scale farmers. In Akwa Ibom State (located in the southern part of Nigeria), for instance, cassava is considered as a cultural crop and is grown in almost all rural households (Akpan et al., 2014). The crop and its chain of derivatives constitute one of the fundamental sources of calorie intake to most Nigerians (Ani, 2010). The utilization of the crop has extended to the industrial sector, export and feed industry among others (Ani et al., 2013 and Akpan et al., 2014).

Referable to the special features of the Southern part of Nigeria such as the soil and water erosion menace as well as high population density; an increase in the production of a predominant arable crop like cassava is likely to be influenced by; excessive land fragmentation and increasing soil degradation or infertility among others (Udoh et al., 2011). Based on the ready established fact that cassava is a traditional and the most important arable crop in the region (Partnership Initiatives in the Niger Delta (PIND), 2011; Sanginga, 2015; Ajayi and Olutumise, 2018), farmers in the time past have adjusted to several agronomic practices in order to increase yields and sustained production (Nweke, et al., 2002). As reported by IITA (2019), more than 400 improved cassava varieties have been developed and released to resource-poor farmers by the combined efforts of the National Root Crop Research Institute and IITA in an attempt to boost productivity and increase the efficiency of farm resource use among farmers. Also, there has been several farm support programmes for cassava farmers. These include input subsidies, establishment of mega processing factories, low and free interest loan schemes and enlistment of states in the region in the Fadama III Additional Financing Scheme, which focused mainly on cassava and rice production in the region (Fadama III AF, 2019, Bassey et al., 2016 and Akwa lbom State Technical Committee on Agriculture and Food Sufficiency (AKSTCASF), 2019). Furthermore, the governments of the region supported other subsidiary services in the cassava value chain in many areas. These include extending processing into many derivatives, off-taking arrangement, price stabilization and quality control as well as export promotion, all in a bid to increase net income of farmers, farm yields and employment in a sustainable manner (Fadama III AF, 2019 and AKSTCASF, 2019). Despite several interventions introduced to upsurge cassava yields and productivity in the region, evidence abounds that a good proportion of cassava farmers in the region have not found their feet on a sustainable or optimum level of technical, economic and allocative efficiencies in farm resource management (Akpan et al., 2017a; Akpan et al., 2017b; Ohen et al., 2014). Experts believed that low efficiencies in resource use in arable crop enterprises are likely to emanate from the low productivity of farm inputs, increase cost of farm investment, decline in output level and continuous increase in income from the alternative land use, among others (Yusuf and Adenegan, 2015; Akanbi, 2015; Akpan, et al., 2017a; Isitor et al., 2017). 
Sustainable technical, economic and allocative efficiencies in this study emphasize the optimization of farm resource use without compromising the ability of the future generations to achieve the same fit amidst the current challenges faced by a small scale cassava enterprise (Brundtland, 1987). An increase in resource use efficiency does not really connote an increase in resource use intensification. This study is built on the assumption that, increase in resource use efficiency is as the result of efficient use or management of farm resources taking into consideration the economic, environmental, political and social as well as cultural hindrances encircling small scale farm enterprises and the need to preserve scare farm resources for future or postponed use. Hence, sustainable farm production is hinged on the efficient management of farm resources now and in the future, taking into consideration the major goals of farm enterprises (Zaman and Gherasim, 2007). As noted by Borza (2014), the need for sustainable production would demand efficient resource management based on an improved method of production. Hence, sustainable farm enterprise is a product of sustainable technical, economic and allocation efficiencies. According to Borza (2014), this approach offers workable options to eradicate poverty and hunger while improving the environmental performance of agriculture.

Despite traditional hindrances, the cassava sub-sector in Akwa Ibom State has witnessed a tremendous improvement in several areas such as; yields, hectarage cultivated and value chain development from 2016 to till date. The state government triggered growth in the subsector by implementing a subsidy programme on selected farms inputs, setting up tractor hiring centres to lower farmers' production cost, registered the state in Fadama III Additional Financing Programme, rehabilitating and putting into use the three mega/integrated cassava processing factories to extend value addition chain and provided incentives to agro-based enterprises that utilized cassava as the raw materials among others. These gestures caused an unprecedented increased in tonnage of raw cassava produced and it's line of value chains. As evidence, the price of cassava and its line of value chains in recent time have remained relatively stable in the state. It is also observed that the volume of cassava and its derivatives brought into the state from other states during this period has greatly reduced and there is a healthy competition in the market across the state. It is obvious that cassava enterprises in the state have undergone positive transformation accompanied by an increase in efficiency of farm resources management. But the important question is; how can this development in the cassava sub-sector in the state be sustained? Concerned about the unsustainable nature of most small scale farmers in Nigeria, Ogunniyi et al. (2012), opined that farm enterprises 'optimum technical and economic efficiencies cannot be achieved unless a sound policy framework is instituted to tackle the issue of insufficient farm inputs especially among resource-poor rural farmers. In order to generate an appropriate policy framework, the pertinent issue of concerned is how to define the range of efficiencies that could be considered as an optimum or sustainable range of efficiencies in small scale farm enterprises. With this rhetorical thought, this study specifically focuses on defining the range 
of efficiencies that could be considered as sustainable among small scale cassava farmers and identifying factors that cause its variability.

\section{Literature Review}

There are several researches on the technical, economic and allocative efficiency of cassava farmers in Nigeria. Below is the recap of some empirical studies in Nigeria.

\section{Determinants of Technical efficiency of cassava farmers}

Simpa et al., (2014) examined the technical efficiency of smallholder cassava farmers in Kogi State. Variables that increased technical efficiency were education, farming experience, and extension agent contacts while age, membership of the farmers' group and household size reduced technical efficiency. Also, Girei et al., (2014) analyzed the productivity and technical efficiency of cassava production in Ardo-Kola and Gassol Local Government Areas of Taraba State. Results showed that gender, age, household size and access to extension services were positive determinants of technical efficiency. In a similar vein, Taiwo et al., (2014) investigated the technical efficiency of cassava farmers in the southwestern region of Nigeria. The result showed an average technical efficiency of 0.904 units. In addition, farmers' age, education, gender, the quantity of fertilizer use, herbicide and access to extension services were identified as positive determinants of technical efficiency. Later, Itam et al., (2015) estimated the technical efficiency of small scale cassava farmers in Cross River State. They discovered the mean technical efficiency of $89 \%$ and further reported that the age and gender of farmers had a negative significant effect on technical efficiency; while education, family size, farming experience, and farm size relate positively. Furthermore, Oduntan et al., (2015) assessed the efficiency and profitability of small-scale cassava production in Akure area of Ondo State. The results showed an average technical efficiency of 0.69 units and also identified education and age as promoters of technical efficiency. Ogunniyi (2015) evaluated technical, allocative and economic efficiencies of cassava farmers in Oyo State in Nigeria. The mean technical efficiency for the farmers was 0.542, while education and farming experience impacted negatively on the technical efficiency. However, access to the extension has a positive impact. In another study, Isitor et al., (2017) investigated the factors affecting technical efficiency of smallholder cassava farmers in Anambra State. The results showed an average technical efficiency of $51.5 \%$ and identified education and access to credit as positive determinants of technical efficiency of cassava farmers. Similarly, Ajayi and Olutumise (2018) investigated the determinants of food security and technical efficiency of cassava farmers in Ondo State. The results indicate that about $80 \%$ of cassava farmers had technical efficiency above 0.50 units, while the average technical efficiency was 0.83 units. Also, results showed that farming experience, education, access to credit, access to extension services and farm size as well as farm income have a positive significant impact on the technical efficiency while household size, distance to the farm and age relate negatively. In recent times, Akerele, et al., (2019) assessed the technical efficiency of small scale 
cassava farmers in Ewekoro Local Government Area of Ogun State. The results revealed that farmers' age, cost of herbicides and cost of planting materials reduces technical efficiency while household size, farming experience and amount of loan increase technical efficiency of the cassava farmers.

\section{Determinants of economic efficiency of cassava farmers}

Some empirical studies have focused on the estimation and the determinants of economic efficiency of cassava farmers in Nigeria. For example, Asogwa et al., (2011) analyzed the economic efficiency of small scale farmers in Benue State. The results revealed that age, education, farming experience, household size, household dependent ratio, and member of social organization were positive determinants of economic efficiency while access to extension services relates in a negative manner. In the same vein, Oladeebo and Oluwaranti (2012) examined the profit efficiency in cassava production in the Southwestern region of Nigeria. The result showed that the mean level of profit efficiency at $79 \%$ and identified household size and farm size as direct determinants of profit efficiency while credit and the amount of agrochemical had a negative relationship. Also, Akpan et al., (2013) estimated translog stochastic profit function for cassava-based farmers in Southern Wetland regions of Cross River State. The results revealed an average economic efficiency of 0.58 and also identified the level of farming involvement, farmer's education, ability to predict rainfall, farming experience, household size, soil management technique adopted, extension agent visits and farm size as significant determinants of profit efficiency of cassava farmers in the region. In addition, Maurice et al., (2015) analyzed cost efficiency in food crop production among small-scale farmers in Adamawa State. The results revealed that extension contact, crop diversification, and credit availability were positive determinants of cost-efficiency. Furthermore, Ettah and Kuye (2017) analyzed profit efficiency of cassava farmers in Cross River State and found the mean profit efficiency of $65 \%$, and also discovered that farming experience and being a member of social organization are positive determinants of profit efficiency. On the other hand, they found farmers' age, education, and household size as negative determinants. Similarly, Akpan et al., (2017a) used a stochastic profit frontier function to estimate farm-level profit efficiency and its determinants among small scale cassava farmers in Oruk Anam Local Government Area of Akwa Ibom State. The report showed that the level of farming involvement, farmers' education; farming experience, household size and soil management technique adopted were positive determinants of economic efficiency while farm size impacted negatively.

\section{Determinants of allocative efficiency of cassava farmers}

Few empirical works have mainly focused on the estimation and determinants of allocative efficiency of cassava farmers in Nigeria. For instance, Ogunniyi (2015) found a negative relationship between allocative efficiency and education as well as farming experience for cassava farmers in Oyo State. However, access to extension services exhibited a positive 
impact. Also, Ibeagwa, et al., (2019) analyzed the determinants of allocative efficiency of smallholder cassava farmers in Ohaji-Egbema Local Government Area of Imo State. The report shows an average allocative efficiency of $56 \%$ and also reveals that household size, educational level, farm size, and experience had positive effects on allocative efficiency while the fixed cost of production had a negative effect.

\section{Research Gap}

Studies on resource use efficiency of cassava farmers have not dealt sufficiently with the issue of sustainable production in Nigeria. To address this pertinent issue, the study was designed to provide information on the sustainability of cassava production, especially among small scale resource-poor farmers using indices of efficiencies. Also, updated information on cassava production efficiency in the southern region of Nigeria is necessary, especially now that emphasis on revenue diversification is focusing on agriculture as the desired destination.

\section{METHODOLOGY}

\section{Study Area}

This study was conducted in Oruk Anam Local Government Area of Akwa Ibom State. The study area is situated in the Southwestern region of the State. Oruk Anam stretches from longitudes $70^{\circ} 30^{\circ} \mathrm{E}$ and $70^{\circ} 50^{\circ} \mathrm{E}$ and latitudes $4^{\circ} 40^{\circ} \mathrm{N}$ with an area of $511.73 \mathrm{~km} \mathrm{sq}$. The area's mean annual rainfall and temperature lie between $2000 \mathrm{~mm}-4000 \mathrm{~mm}$ and $26{ }^{\circ} \mathrm{C}$ $28^{\circ} \mathrm{C}$ respectively. It is an agrarian community.

\section{Sample Size Selection}

Following Cochran (1963), a representative sample from a large population is obtained using the equation (1):

$S_{n}=\frac{z^{2} \rho(1-P)}{D^{2}}$

The variables are as defined below:

$\mathrm{S}_{\mathrm{n}}=$ representative sample

$Z=95 \%$ confidence level (1.96).

$P=$ proportion of cassava farmers in the total number of farmers in the study area (95\%)

$D=$ absolute error or precision at $5 \%$ type 1 error.

$$
S_{n}=\frac{(1.96)^{2} 0.95(1-0.95)}{(0.05)^{2}}=73
$$

For proportional sample across selected villages, the sample size was scaled up to 100 respondents. 


\section{Sampling Techniques and Sample Size}

A three-stage random sampling method was adopted to pick respondents in the selected villages. Oruk Anam has nine Clans. Five clans were randomly selected in the first stage. In the second stage; two villages where cassava production is prominent were randomly selected from each clan. Ten villages were selected in all for data collection. In the third stage, ten cassava farmers were randomly picked from each village. A grand total of one hundred cassava farmers picked and used for data collection in the study.

\section{Method of Data Collection}

Data were collected using a structured questionnaire. The study also employed complementary interview system where key informants in each village were interviewed to authenticate the information provided by the farmers. This was done to ensure consistency and accuracy of information collected. A series of cross-sectional data were collected, scrutinized and used for data analysis.

\section{Analytical Techniques}

The study is modeled following theories of production and resource use efficiency. Farmers are assumed to be rational in all aspects and will also thrive to maintain production close to the frontier to ensure optimum profit and sustainability of farm enterprises.

\section{Estimating Technical Efficiency Indices}

Technical efficiency indices were generated using Cobb Douglass stochastic production function as specified as thus:

$$
\begin{aligned}
\log C A O=\delta_{0} & +\delta_{1} \operatorname{LogLan}+\delta_{2} \operatorname{LogHhl}+\delta_{3} \operatorname{LogHil}+\delta_{4} \operatorname{LogFer}+\delta_{5} \operatorname{LogCaS} \\
& +\delta_{6} \operatorname{LogCap}+\delta_{7} \operatorname{LogMan} \\
& +\left(V_{1}-U_{1}\right) \ldots \ldots \ldots \ldots \ldots \ldots \ldots \ldots \ldots(3)
\end{aligned}
$$

Where,

$\mathrm{CAO}=$ Output of cassava measured in $(\mathrm{kg})$

LAN $=\quad$ Land size of farmer measured in hectares

$\mathrm{HHL}=$ Household labour (mandays)

$\mathrm{HIL}=$ Hired labour (mandays)

FER = Quantity of Fertilizer $(\mathrm{Kg})$

CAS $=$ Cassava Stem cutting $(\mathrm{kg})$

$\mathrm{CAP}=$ Depreciation value of farm asset as proxy of farm capital (Naira)

MAN = Quantity of Manure measure in $\mathrm{kg}$

$(\mathrm{Vi}-\mathrm{Ui})=\quad$ Composite error term

\section{Estimating Economic Efficiency Indices}

Profit efficiency (or economic efficiency) indices were generated using the stochastic profit function. Implicitly, the used stochastic profit function is specified as thus: 


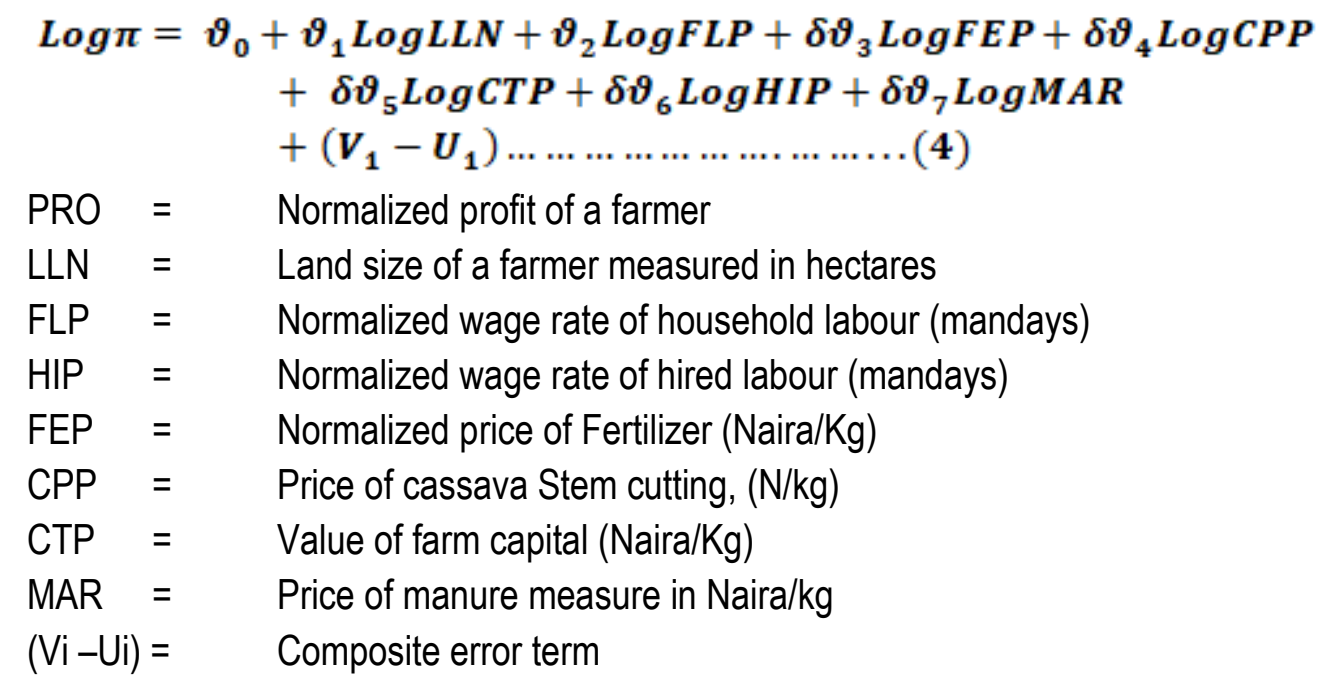

Note that all monetary variables were normalized using output price.

\section{Estimating Farm-Specific Allocative Efficiency}

Following the work of Martin and Taylor, (2003), farm-specific allocative efficiency (AE) index was generated from the estimated technical efficiency (TE) and profit efficiency (EE) in the relationship described in equation (5):

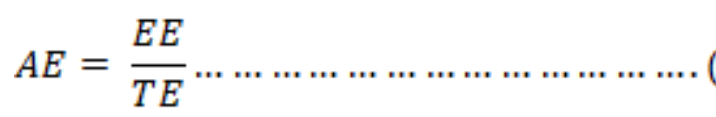

\section{Measuring sustainable farm level technical, economic and allocative efficiencies}

In this study, sustainable efficiency index of a single firm from a group of similar firms perceived as the range of efficiency that is identical to or greater than the average efficiency, but not exceeding the maximum efficiency obtained by a firm or firms in that group. Given a group of single output enterprise, it will require efficient management of scare firm resources for a member to operate on the average efficiency range of the group. Also, given the small nature of firms considered in the study and the underlying assumption of Cobb Douglas production function; it is assumed that the majority of farm firms will rather thrive hard to attain the average efficiency level and above in farm resource management in order to sustain the business for a long time. And also considering the fact that frontier efficiency is not sustainable because resources could be overstressed and this could result in the collapse of the entire production process. Hence, the decision for a farm firm to sustain the efficient management of farm resources is assumed to be a product of equal pressures of economic circumstances, cultural and political pressures as well as social and climatic environments among others. On the basis of sustainability of small scale farming, this study considered 
sustainable farm resource efficiency indices as ranging from the average efficiency to the maximum efficiency (but not up to the frontier efficiency) obtained by a firm in the same category of production. In a more explicit form, we defined sustainable efficiency $\left(Y_{i}\right)$ of a small scale farm or firm as:

\section{$Y_{i}=$ Technical efficiency, Economic ef ficiency, Allocative efficiency \\ $\geq$ Threshold or average ef ficiency but \\ $<$ frontier efficiency.}

Hence, given:

Efficiency Index equation $Y_{i}^{*}$

$$
=X_{I i}^{\prime} \beta_{1}+\left(V_{1}-U_{1}\right)
$$

Threshold equation $Y_{i}$

$$
=\left\{Y_{i}^{*} \text { if } Y_{i}^{*} \geq M E<F E \text {, and is } 0 \text { if } Y_{i}^{*}<M E<F E\right\}
$$

In a more explicit mathematical form it is given thus:

$Y_{i}=Y_{i}^{*}=X_{1 i}^{\prime} \beta_{1 i}+\left(V_{1}-U_{1}\right)$ if $X_{1 i}^{\prime} \beta_{1}+\left(V_{1}-U_{1}\right) \geq M E<F E$

$Y_{i}=0=X_{1 i}^{t} \beta_{1 i}+\left(V_{1}-U_{1}\right)$ if $X_{1 i}^{t} \beta_{1}+\left(V_{1}-U_{1}\right)<M E<F E$

Where $Y_{i}^{*}$ is the farm level efficiency index derived from the stochastic production and profit functions, note $Y_{i}^{*}$ is also called a latent variable. $X_{I i}^{\prime}$ is a vector of farm resource used in the production and profit function and $\beta_{i}$ is a vector of production elasticity, $Y_{i}$ is the observed or sustainable efficiency of a farm; ME is the threshold or average efficiency index of a group of farms; while FE denotes frontier efficiency.

A censored model, which closely resembles censored Tobit's model, is expressed as shown in equation 9 .

$Y_{i}=Y^{*}=X_{2 i}^{t} \beta_{2 i}+V_{i}, \quad V_{i} \sim N\left(0 . \delta^{2}\right)$

$Y_{i}$ is the observed optimum farm efficiency which is defined as $Y_{i}^{*}$ or is zero (0), $X_{2 i}^{\prime}$ represents explanatory variables consisting of farmers' specific, economic, social, environmental and climatic factors influencing the sustainable efficiency of farms.

Explicitly, the explanatory variable in the censored Tobit's model is stated as thus:

$$
\begin{aligned}
& Y_{i}=Y^{k}=\beta_{0}+\beta_{1} A G E+\beta_{2} E D U+\beta_{3} G E N+\beta_{4} E P P+\beta_{5} H H F+\beta_{6} F A S \\
& +\beta_{7} S O C \\
& +\beta_{8} P O V+\beta_{9} T I L L+\beta_{10} F E R+\beta_{11} M A N+u
\end{aligned}
$$




$\begin{array}{lll}\text { EDU }= & \text { Education level of the farmer } \\ \text { GEN }= & \text { Gender (female }=1 \text { and } 0=\text { male) } \\ \text { EPP }= & \text { Farming experience is measured in years } \\ \text { HHF }= & \text { Household size (number) } \\ \text { FAS }= & \text { Farm size (ha) } \\ \text { SOC }= & \text { Membership in a social organization (Number of years) } \\ \text { POV }= & \text { Poverty status of household head (income below the poverty line of } \\ \text { TILL }= & \text { respondents) } \\ \text { FER }= & \text { Quantity of fertilizer used in kg } \\ \text { MAB }= & \text { Quantity of manure used in } \mathrm{kg}\end{array}$

\section{Marginal Effects for censored Tobit Model}

McDonald and Moffitt (1980) decomposed total the marginal effects of the censored Tobit model into various components. Originally, Tobit marginal effect on the expected value for $y$ which consists of those of censored and uncensored variables. Hence,

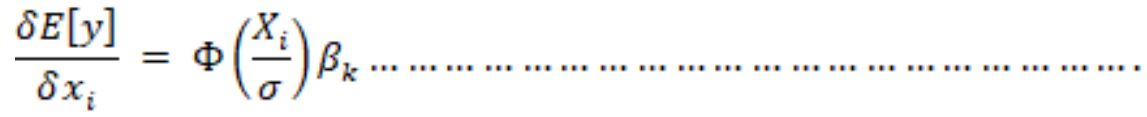

$$
\begin{aligned}
& \frac{\delta E[y]}{\delta x_{i}}=P(y>0) \frac{\delta E[y \mid y>0]}{\delta x_{i}}+E[y \mid y>0] \frac{\delta P(y>0)}{\delta x_{i}}
\end{aligned}
$$

This is called McDonald and Moffitt's (1980) decomposition. It allows us to see that a change in $X_{i}$ affects the conditional mean of $y^{*}$ in the positive part of the distribution and it affects the probability that the observation will fall in that part of the distribution. Using equation 9 , the total marginal effect is divided into three portions as follows:

(a) Marginal effect on the latent dependent variable, $\left(y^{*}\right)$.

$\frac{\delta E\left(y^{*}\right)}{\delta x_{i}}=\beta_{i}$

Hence, the above Tobit coefficients indicate how a one-unit change in an independent variable $x_{i}$ alters the latent dependent variable.

(b) Marginal effect on the expected value for $y$ for uncensored observations)

$$
\frac{\delta[y \mid y>0]}{\delta x_{i}}=\beta_{i}\left\{1-\lambda(\alpha)\left[\frac{X_{i} \beta}{\sigma}+\lambda(\alpha)\right]\right\} \ldots
$$


Where $\lambda(\boldsymbol{\alpha})=\frac{\phi\left(\frac{X_{i \beta}}{\sigma}\right)}{\Phi\left(\frac{X_{i \beta}}{\sigma}\right)}$ and this indicates how a one-unit change in an independent variable $X_{i}$ affects uncensored observations.

(c) The probability of being uncensored

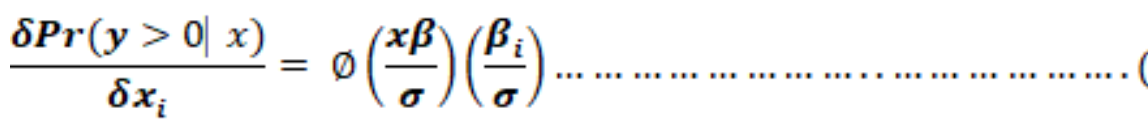

\section{RESULTS AND DISCUSSION}

\section{Estimates of Cobb-Douglas production and Profit functions for cassava farms}

Results in Table 1 shows the diagnostic tests for the estimates of the specified Cobb Douglas production and profit functions of cassava farms (note, maximum likelihood estimation method was used). Values of sigma square 0.04817 and 0.70088 for production and profit function, respectively, are statistically significant at $1.0 \%$ probability level. This shows the correctness of the assumption of the composite error term for the specified models and also implied goodness of fit for the data. The variance ratio coefficients of 0.7009 ) and 0.72607 for production and profit functions respectively, are high, suggesting that the systematic effects that are not captured in the estimated functions are relatively dominant random error sources. This result means that the existence of inefficiency in resource management among the respondents in the study area accounted for about $70.1 \%$ and $72.61 \%$ variation in the output and profit earned respectively by cassava farms. The presence of the dominant one-sided error component in the specified model is thus confirmed, implying that the Ordinary Least Squares estimation method would be an inadequate representation of the data.

Table 1: Diagnostic test for the production and Profit efficiency models

\begin{tabular}{lcc}
\hline Diagnostic Test Coefficient & $\begin{array}{c}\text { Standard error } \\
\text { Economic Efficiency Model }\end{array}$ & t-test \\
& &
\end{tabular}

\begin{tabular}{lccc}
\hline Sigma Square & 0.701 & 0.120 & $5.819^{* * \star}$ \\
Gamma & 0.726 & 0.010 & $2.581^{* * *}$ \\
Log likelihood Function & -12.093 & & \\
\hline & \multicolumn{4}{c}{ Technical Efficiency Model } \\
\hline Sigma squared & 0.048 & 0.01162 & $4.144^{* * *}$ \\
Gamma & 0.701 & 0.18450 & $3.799^{* * *}$ \\
Log likelihood ratio & 1.954 & & \\
LR test & 5.748 & & \\
\hline
\end{tabular}

Source: From data analysis derived from frontier 4.1 programme. 
Results in Table 2 showed the summary statistics of the estimated indices of the efficiencies of the cassava farms sampled. The findings revealed the mean value of $0.683,0.173$ and 0.249 for technical, economic and allocative efficiency respectively. Also, sustainable technical, economic and allocative efficiencies averaged at $0.86,0.304$ and 0.384 respectively. These results indicate that it will require a farmer with the least sustainable technical, economic and allocative efficiency to acquire an efficiency gain of $0.147,0.239$ and 0.404 respectively to be at the best sustainable efficiency point in the production surface.

Table 2: Summary Statistics for technical, Economic and Allocative Efficiencies

\begin{tabular}{lcccccc}
\hline Statistic & TE & EE & AE & SUTE & SUEE & SUAE \\
\hline Mean & 0.6834 & 0.1727 & 0.2499 & 0.8162 & 0.3037 & 0.3842 \\
Minimum & 0.3660 & 0.1000 & 0.1055 & 0.6873 & 0.1768 & 0.2629 \\
Maximum & 0.9630 & 0.5435 & 0.7883 & 0.9630 & 0.5435 & 0.7883 \\
Standard deviation & 0.1593 & 0.1079 & 0.1265 & 0.0883 & 0.1084 & 0.1284 \\
Coefficient of & 0.2331 & 0.6247 & 0.5061 & 0.1081 & 0.3570 & 0.3343 \\
variability & & & & & & \\
Skewness & 0.0020 & 1.7806 & 1.9133 & 0.1103 & 0.7898 & 1.8144 \\
Ext.kurtosis & -0.9902 & 2.5040 & 4.8932 & -1.3728 & -0.3226 & 3.4399 \\
\% of respondents & 100 & 100 & 100 & 50 & 31 & 34 \\
\hline
\end{tabular}

Source: Computed by authors, data obtained from field survey conducted in 2018. Note; SUTE, SUEE, and SUAE, represent sustainable technical, economic and allocative efficiency respectively.

For technical efficiency indices, sustainable technical efficiency lies from 0.8162 to 0.9630 , which implies that there is still room for the farmers' to increase the upper limit of sustainable technical efficiency. Results reveal that only $50 \%$ of the sampled farmers operated on a sustainable technical efficiency range. However, the upper limit of the profit efficiency was far $(0.4565)$ from the frontier efficiency. About $31 \%$ of farmers operate in the sustainable profit efficiency range. The upper limit boundary of the economic sustainable efficiency range is 0.46 far from the frontier curve. The result supported the small scale nature of production and low farm investment that often characterized small scale farmers in developing countries. Given the result, it is obvious that respondents still have plentiful opportunities to manipulate resource combination or adopt cost-effective/minimization production in order to expand the profit margin. The distribution of sustainable allocative efficiency indicates that the farmers still have a lot to learn from the sustainable resource mix that produces equality of marginal social benefit and marginal social cost. Only $34 \%$ of the farmers operated in the sustainable allocative efficiency range that lies from 0.2499 to 0.7883 . 


\section{Test for multicollinearity}

The results in Table 3showed the variance inflating factor (VIF) estimates of the explanatory variables used. The result reveals no significant incidence of collinearity among the independent variables fitted in the model. The estimates of VIF are below the threshold of 10 units. The result suggests that the explanatory variables are independently distributed and hence show the insignificance level of multicollinearity. The tolerance factor of each explanatory variable (which is the reciprocal of the variance inflating factor (VIF)) is below unity. This indicates that the incidence of multi-collinearity in the explanatory variables is insignificant. The finding implies that the coefficients of the estimated censored Tobit model are consistent and unbiased.

Table 3: Test for multicollinearity

\begin{tabular}{lcc}
\hline Variable & Estimate of VIF & Tolerance estimate \\
\hline AGE & 2.547 & 0.3926 \\
EXP & 2.997 & 0.3337 \\
SOC & 1.359 & 0.7358 \\
EDUCATION & 1.371 & 0.7294 \\
HOUSEHOLD SIZE & 2.010 & 0.4975 \\
FARM SIZE & 2.064 & 0.4845 \\
GENDER & 1.526 & 0.6553 \\
POVERTY LEVEL & 1.146 & 0.8726 \\
TILLAGE & 1.279 & 0.7819 \\
FERTILIZER & 1.254 & 0.7974 \\
MANURE & 2.608 & 0.3834 \\
FARM CAPITAL & 3.052 & 0.3277 \\
\hline SOUI
\end{tabular}

Source: Computed by authors, 2019.VIF means Variance Inflation Factor

Determinants of sustainable technical efficiency of cassava farms in the study area

The estimates of the censored Tobit model representing sustainable technical efficiency are presented in Table 4. The diagnostic tests reveal that about $55 \%$ of the variations in the indices of sustainable technical efficiency of cassava farms are attributed to the specified explanatory variables. The normality test confirms the symmetric nature of the estimated error term. The model also showed the goodness of fit as attested for by the significant nature of the $\mathrm{F}$ statistic and the Chi-square value. The results reveal that years of farmers' formal education are a positive determinant of the attainment of sustainable technical efficiency in cassava production. A unit increase in the year of formal education of farmers would likely increase the probability of attaining sustainable technical efficiency by 0.0049 units. This implies that the more cassava farmers' acquired formal education, the greater their chances of operating in the range of sustainable technical efficiency. Increase in years of formal education has a strong affiliation to the efficient management of farm resources and 
innovation adoption as well as adaptation of sustainable farm practices. Positive relationship between technical efficiency and years of formal education has been reported by Taiwo et al., (2014), Itam et al., (2015), Ogunniyi (2015), Oduntan et al., (2015) and Isitor et al., (2017), Ajayi and Olutumise (2018) in Nigeria.

Table 4: Determinants of sustainable technical efficiency for Cassava farmers

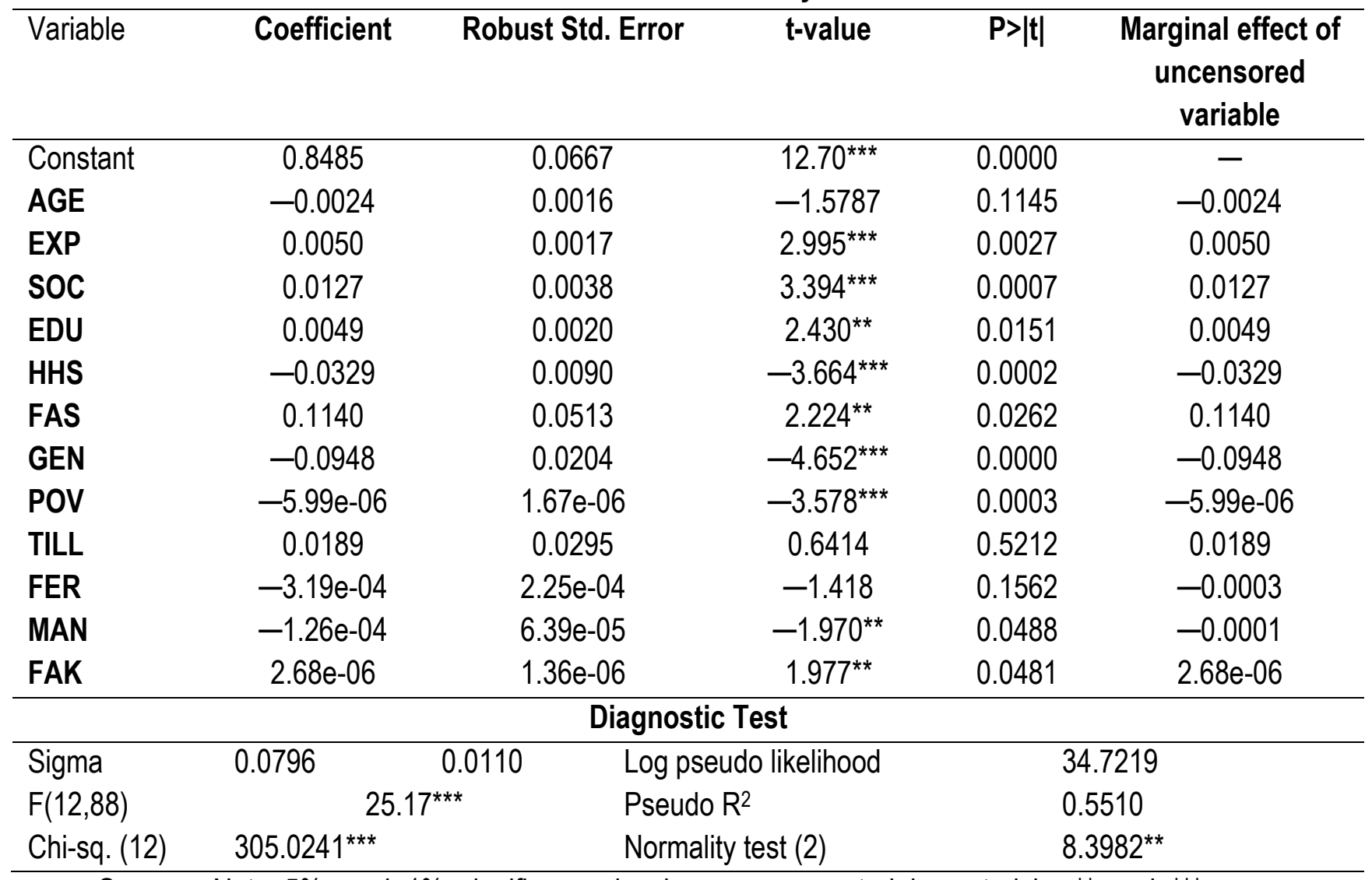

Source: Note $5 \%$, and $1 \%$ significance levels are represented by asterisks ${ }^{* *}$ and ${ }^{* * *}$ respectively.

Likewise, farming experience, farm size and belonging to social organization(s) as well as farm capital have a positive relationship with the attainment of sustainable technical efficiency among the cassava farmers in the study area. For instance, a $1 \%$ increase in these variables would cause a corresponding increase in sustainable technical efficiency by $0.005,0.114$, 0.0127 and 0.0000027 units respectively. Mounting farming experience increases the possibility of obtaining an efficient farm resource mix and the aversion of farm risks and uncertainty situations. Farming experience is also positively related to the adoption of innovations and efficient farm practices. The correlation between sustainable technical efficiency and farming experience obtained in the study corroborates the findings of; Simpa et al., (2014), Itam et al., (2015) and Akerele, et al., (2019) but is contrary to Ogunniyi (2015). 
Also, an increase in farm size increases the economies of scale of farmers and horizon for several resource combinations. An increase in farm size has been often an incentive to increase farm resource used, farm output and hike commercialization of farm produce and it's the most important factor that influences the attainment of sustainable technical efficiency as shown by the magnitude of its marginal effect. Itam et al., (2015) and Ajayi and Olutumise (2018) have submitted similar result between technical efficiency indices and farm size.

In a similar Vein, the relationship with social interactions or membership of a social organization implies that, as social capital is accumulated among cassava farmers, the attainment of sustainable efficiency range increases correspondingly. An increase in social capital is often accompanied by an increase in the opportunity to share farm experiences, increase market share and financial benefits from cooperative ventures. The overall benefits of an increase in social capital to farmers, in the long run, include an increase in farm net investments. An increase in net farm investment has the tendency to increase farm input acquisition and adoption of sustainable and cost-effective, driven technology, which enhances the efficient use of farm resources. In addition, an increase in farm capital is an indication of an increase in farm income and investment. Improvement in farm capital ensures a reduction in overall production cost and an increase in farm net profit, which is evidence of the sustainability of farm enterprises. However, the result contradicts the report of Simpa et al., (2014)

On the contrary, gender (female composition), household size, level of poverty and quantity of manure used by cassava farmers impacted negatively on the attainment of sustainable technical efficiency by cassava farmers in the study area. The finding implies that, as the proportion of female cassava farmers increase, the tendency of attaining sustainable technical efficiency in resource used decreases correspondingly. For instance, a one percent increase in female composition of cassava farmers would result in a 0.0948 units' reduction in sustainable technical efficiency. The result further suggests that female cassava farmers may likely have limited power or right to independently owned and managed farm resources compared to the male counterpart. This suggestion is strongly connected to the cultural believed and norms of most communities in the study area where absolute power is assigned to male folk over ownership and management of societal resources. Since female members do not have full control of farm, resource, there is the possibility that they will not make the best of decisions in resource management. The finding is in consonance with the report of Itam et al., (2015) but contradict the reports submitted by Girei et al., (2014) and Taiwo et al., (2014).

In a similar Vein, an increase in household size would likely increase family household expenditure and reduce aggregate farm investment. Following this assertion, certain farm practices and innovations that would have helped to increase efficient resource use would likely be traded off in place of family demand. The overall impact will be the reduction in efficiency of resource mix which will likely result in inefficiency in resource use. The result is in 
agreement with the reports of Simpa et al., (2014), Girei et al., (2014) and Ajayi and Olutumise (2018) but however controvert the reports of Itam et al., (2015) and Akerele, et al., (2019).

Similarly, continuous use of manure will increase the total farm expenditure and mostly the required quantity needed by farmers is often out of the reach for most of them due to the hike in price. In addition, the quality of manure available instead of improving soil fertility causes soil toxicity. That is, the composition of most organic manure, especially the poultry manure contains heavy and toxic chemicals which are capable of affecting soil fertility. Other reasons are connected to cultural belief and agronomical requirements as well as underground water pollution among others. A similar report from Taiwo et al., (2014) and Akerele, et al., (2019) have been established previously.

\section{Determinants of sustainable economic efficiency of cassava farms in the study area}

The estimated sustainable economic efficiency function for cassava-based farms is shown in Table 5. A significant proportion of the variation in sustainable economic efficiency is attributed to the independent variables fitted in the model. The estimated model has the goodness of fit as attested for by the significant nature of the F-calculated and other important indicators. The results indicate that the year of farmers' formal education, the proportion of female cassava farmers, years of farming experience, land size and the adoption of the tillage, soil management technique are positive determinants of sustainable economic efficiency among cassava farms in the Oruk Anam area. The finding implies that the use of tillage, soil management technology is capable of increasing revenue allotted to farmers through an increase in farm yields. The finding is in concordance with Akpan et al., (2013) and Akpan et al., (2017b) reports.

Also, an increase in farmers' education and farming experience are incentives to achieving better management of farm resources, including the adoption of the best agronomic practices among others. Input price bargaining and other marketing practices, efficiencies, increase with an increase in farmers' educational level and experience. Perhaps an increase in years of formal education would increase the farmers' ability to manage farm resources efficiently by adopting cost minimization strategies. The same is applicable to farming experience and years in social organization. The increase in these variables would tend to increase the managerial ability of farmers and the adoption of the best and cost-effective farm innovations that likely resulted in the attainment of sustainable economic or profit efficiency. Furthermore, increment in farmland size implies an increase in economies of scale and farm investment potentials. The likely resultant effects would include increases in the commercialization of farm enterprises leading to an increase in farmers' revenue. The finding corresponds to research reports of Asogwa et al., (2011), Akpan et al., (2013), Ettah and Kuye (2017), Akpan et al., (2017b), but is contrary to Ettah and Kuye (2017). 
Farm size has continued to exhibit a prominent role in the attainment of sustainable profit or efficiency in small scale cassava production in the study area. This is often manifested in the form of economies of scale with an accompanying increase in yield/returns and market share (Oladeebo and Oluwaranti, 2012; Akpan et al., 2013; and Akpan et al., 2017b)

On the other hand, household size and the increased use of fertilizer constitute a serious impediment to the attainment of sustainable economic efficiency among small scale cassava farms in the study area. This could be attributed to the fact that an increase in household size would likely increase family expenditure which will have a negative impact on the gross farm investment. Also, a relatively high price of fertilizer and its deteriorating qualities have rather resulted to increase in the total cost of production thereby reducing the net return on farm investment.

Table 5: Determinants of optimum profit efficiency for cassava farmers

\begin{tabular}{lccccc}
\hline Variable & Coefficient & $\begin{array}{c}\text { Robust Std. } \\
\text { Error }\end{array}$ & t-value & P $>|t|$ & $\begin{array}{c}\text { Marginal effect of } \\
\text { uncensored } \\
\text { variable }\end{array}$ \\
\hline Constant & -0.477 & 0.133 & $-3.590^{* * *}$ & 0.001 & - \\
AGE & 0.004 & 0.002 & 1.600 & 0.113 & 0.0036 \\
EXP & 0.010 & 0.002 & $4.050^{* * *}$ & 0.000 & 0.0101 \\
SOC & 0.006 & 0.005 & 1.360 & 0.179 & 0.0063 \\
EDU & 0.005 & 0.002 & $2.670^{* * *}$ & 0.009 & 0.0048 \\
HHS & -0.035 & 0.008 & $-4.510^{* * *}$ & 0.000 & -0.0348 \\
FAS & 0.515 & 0.094 & $5.500^{* * *}$ & 0.000 & 0.5152 \\
GEN & 0.094 & 0.035 & $2.720^{* * *}$ & 0.008 & 0.0938 \\
POV & $-3.32 \mathrm{e}-06$ & $7.16 \mathrm{e}-06$ & -0.460 & 0.644 & $-3.32 \mathrm{e}-06$ \\
TILL & 0.079 & 0.031 & $2.550^{* *}$ & 0.013 & 0.0793 \\
FER & $-8.04 \mathrm{e}-04$ & $2.69 \mathrm{e}-04$ & $-2.990^{* * *}$ & 0.004 & -0.0008 \\
MAN & $-3.22 \mathrm{e}-05$ & $5.55 \mathrm{e}-05$ & -0.580 & 0.564 & $-3.22 \mathrm{e}-05$ \\
FAK & $1.23 \mathrm{e}-06$ & $1.68 \mathrm{e}-06$ & 0.730 & 0.468 & $1.23 \mathrm{e}-06$ \\
\hline \multicolumn{7}{c}{ Diagnostic Test } \\
\hline Sigma & 0.0701 & 0.0102 & Log pseudo likelihood \\
F(12,88) & \multicolumn{7}{c}{ Pseudo R } & 29.2476 \\
\hline
\end{tabular}

Source: Note, $5 \%$, and $1 \%$ significance level are represented by asterisks, ${ }^{* *}$ and ${ }^{* * *}$ respectively.

An increase in household size increases farm household expenditure and stiffens farm investment. The issue of fertilizer usage in small scale farming in developing is mostly tight to unavailability and high price as well as the poor quality. These phenomena have contributed to the inefficiency in fertilizer use in small scale farming in the region. Considering the 
magnitude of the marginal effect of explanatory variables, farm size, tillage and farming technology, and farming experience is the dominant factors influencing sustainable economic efficiency in small cassava farms in the study area. The finding has been reported previously by Asogwa et al., (2011); Oladeebo and Oluwaranti (2012); Akpan et al., (2013); and Akpan et al., (2017b). Nevertheless, the finding is in discordance with the submission of Ettah and Kuye (2017) with regards to training.

\section{Determinants of sustainable allocative efficiency of cassava farms in Akwa lbom State}

The estimates of sustainable allocative efficiency model for the small scale cassava farmers in the study area are shown in Table 6. The estimated F-statistic is significant at $1 \%$ probability level. About $62 \%$ of the variations in the sustainable allocative efficiency can be traced to the specified explanatory variables, hence the model has goodness of fit. The results showed that the coefficients of farmers' age, the year of farmers' formal education; the proportion of female farmers, years of farming experience, farmland size and adoption of tillage soil management techniques are positive and significant at acceptable probability levels. This implies that an increase in these variables would result in the corresponding increase in sustainable allocative efficiency among cassava farms in the study area.

An increase in farmers' age and formal education, as well as farming experience, has a strong correlation with the adaptive behaviour of farmers. As these variables increase among farmers, the optimal mix of farm resources and the knowledge of the pattern of consumer demand increase and these tend to upsurge allocative efficiency. An increase in farm size would expand farmer's horizons of experimenting with several farm resource mix and increase in marginal social benefit; whereas an increase in the use of soil tillage enhances output yield and hence, allocative efficiency of farmers. Ibeagwa et al., (2019) has reported similar results.

On the contrary, farmers' household size and quantity of fertilizer used to impact negatively on the attainment of sustainable allocative efficiency of their farms. Judging from the size of marginal effect estimated, farm size, gender, farming experience, and household size played more predominant roles in influencing the sustainable allocative efficiency of cassava farm in the study area. 
Table 6: Determinants of optimum allocative efficiency for cassava farmers

\begin{tabular}{lccccc}
\hline Variable & Coefficient & $\begin{array}{c}\text { Robust Std. } \\
\text { Error }\end{array}$ & t-value & P>|t| & $\begin{array}{c}\text { Marginal effect of } \\
\text { uncensored } \\
\text { variable }\end{array}$ \\
\hline Constant & -0.6004 & 0.2065 & $-2.9100^{* * *}$ & 0.0050 & - \\
AGE & 0.0054 & 0.0027 & $1.9800^{*}$ & 0.0510 & 0.0054 \\
EXP & 0.0093 & 0.0031 & $2.9800^{* * *}$ & 0.0040 & 0.0093 \\
SOC & -0.0036 & 0.0076 & -0.4700 & 0.6360 & -0.0036 \\
EDU & 0.0054 & 0.0018 & $3.0000^{* * *}$ & 0.0030 & 0.0054 \\
HHS & -0.0251 & 0.0117 & $-2.1400^{* *}$ & 0.0350 & -0.0251 \\
FAS & 0.5172 & 0.1283 & $4.0300^{* * *}$ & 0.0000 & 0.5172 \\
GEN & 0.1715 & 0.0561 & $3.0600^{* * *}$ & 0.0030 & 0.1715 \\
POV & $4.95 \mathrm{e}-06$ & $3.79 \mathrm{e}-06$ & 1.3000 & 0.1950 & $4.95 \mathrm{e}-06$ \\
TILL & 0.0931 & 0.0318 & $2.9200^{* * *}$ & 0.0040 & 0.0931 \\
FER & -0.0006 & 0.0003 & $-1.8900^{*}$ & 0.0620 & $-6.19 \mathrm{e}-04$ \\
MAN & $2.33 \mathrm{e}-05$ & $8.10 \mathrm{e}-05$ & 0.2900 & 0.7740 & $2.33 \mathrm{e}-05$ \\
FAK & $6.70 \mathrm{e}-07$ & $2.03 \mathrm{e}-06$ & 0.3300 & 0.7420 & $6.70 \mathrm{e}-07$ \\
\hline \multicolumn{7}{c}{ Diagnostic Test } \\
\hline Sigma & 0.0701 & 0.0102 & Log pseudo likelihood \\
F(12,88) & $23.19^{* * *}$ & Pseudo R & 35.3964 \\
\hline
\end{tabular}

Source: Note, $5 \%$, and $1 \%$ probability levels are represented by asterisks,

${ }^{* *}$ and ${ }^{* * *}$ respectively.

\section{CONCLUSION AND RECOMMENDATIONS}

Sustainable production of crops among small scale farmers is a key to reducing food deficit in developing countries. For instance, governments in Nigeria have initiated several programmes to expand the scale of production based on the adoption of large scale farming; but it is obvious that the production is still dominated by small scale farmers. A new dimension to the issue of sustainable crop production has suddenly turned to increasing productivity in the context of small scale farming and adopting sustainable farm practices amidst increasing pressure on land by alternative uses. The study proposes the range of sustainable technical, economic and allocative efficiencies and estimates factors that affect it. Only $50 \%, 31 \%$ and $34 \%$ of respondents operated in the range of sustainable technical, economic and allocative efficiency respectively. Availability of land and the social capital accumulation seem to be the most important decisive factors for attaining sustainable technical, economic and allocative efficiencies in small scale cassava production in the study area. Several policy variables such as the farmers' level of education, household size, quantity of manure and fertilizer used were identified in the study. Based on the findings, the 
following recommendations are necessary if sustainable technical, economic and allocative efficiencies are to be achieved in small scale cassava production in the region.

1. Formation of the farmers' group should be prioritized among small scale arable crop farmers in the region

2. Government, NGOs', farmer groups, agencies, churches, and communities should encourage adult education, especially in rural farming communities of the State

3. Stakeholders in agriculture (such as community leaders, government, churches, NGOs, and Institutions) should encourage and promote family planning in farming communities of the State.

4. All Stakeholders (such as community leaders, government, churches, NGOs, and Institutions) should promote and ensure the formation of policies that would encourage the formation of social capital among small scale farmers in the region.

5. Specialized agency, Institutions and relevant government research outfits should carry out researches with the aim of producing quality blended and cost-effective organic manure for use by small scale arable crop farmers in the State.

6. The development of Greenfield should be subsidized by the State government. This will help to increase the farm size of small scale farmers.

7. Good quality fertilizer is absolutely necessary for the achievement of sustainable technical, economic and allocative efficiencies in small scale arable crop production in the State.

8. Cassava farmers should be encouraged to adopt tillage technology and this should be incorporated into the State extension service delivery component.

\section{REFERENCES}

Adeyemo, R., Oke, J.T.O., and Akinola, A.A. (2010). Economic Efficiency of Small Scale Farmers in Ogun State, Nigeria. Tropicultura, 28(2), 84-88.

Ajayi, C.O., and Olutumise, A.I. (2018). Determinants of food security and technical efficiency of cassava farmers in Ondo State, Nigeria. International Food and Agribusiness Management Review, 21 (7), 915 - 928

Akanbi, S.O. (2015). The analysis of technical and cost efficiency of cultured Fish production in Kwara State, Nigeria. Agrosearch; 15(2), 59 - 72.

Akerele, E.O., Akerele, E.F., Onasanya A.S., Akomolede L.A. (2019). Technical Efficiency of Small-Scale Cassava Farmers in Ogun State, Nigeria. International Journal of Innovative Agriculture \& Biology Research, 7 (1), 60-69.

Akpan, S. B., Adah, A. J. and Udoh, E.J. (2017a). Assessment of Farm factor productivity of small scale cassava farmers in OrukAnam Local Government Area of Akwa lbom 
State, Nigeria. Nigerian Journal of Agriculture, Food and Environment, 13 (1), 113120.

Akpan, S.B., Ini-mfon V., Samuel J., \& Udoro J.U. (2014). Monthly Price Analysis of Cassava Derivatives in Rural and Urban Markets in Akwa Ibom State, Southern Nigeria. Journal of Agricultural Science, 2(1), 48-68.

Akpan, S.B., Udoh, E.J. and Adah, A.J. (2017b). Analysis of Economic Efficiency and Perceived Constraints to small scale Cassava Production in OrukAnam Local Government Area of Akwa Ibom State, Nigeria. International Journal of Agriculture and Rural Development, 20(1), 2951-2961.

Akpan, S. B.,Uwemedimo E. O., Elizabeth N. J., Kesit, K. N., and Daniel, E. J., (2013). Economic Efficiency of Cassava Based Farmers in Southern Wetland Region of Cross River State, Nigeria: A Translog Model Approach. International Journal of Humanities and Social Science, 3,(12), 173-181.

Akwa Ibom State Technical Committee on Agriculture and Food Sufficiency (2019). Hard document of the Committee showing a comprehensive Report of the Committee from 2015 to 2019.

Ani, S. O., Agbugba, I. K., and Lloyd J.S. Baiyegunhi (2013). Processing and Marketing of Selected Cassava Products in Southeast Nigeria. Journal of Economics, 4(2), 105-111.

Ani, S.O. (2010). Comparative Economic Analysis of Selected Cassava Derivatives in UzoUwani Local Government Area of Enugu State. MSc Research Work, Unpublished. Department of Agricultural Economics, University of Nigeria, Nsukka.

Asogwa, B. C., Umeh, J. C., and Penda, S. T. (2011). Analysis of Economic Efficiency of Nigerian Small Scale Farmers: A Parametric Frontier Approach. Journal of Economics, 2(2), 89-98.

Bassey, N.E., Ndiyo, N.A., and Ibia, O.K. (2016). Rural Development Programmes and Sustainable Development in Nigeria: A Case study of Cross River State MultiDisciplinary. Journal of Research and Development Perspective, 5(1), 63-68.

Borza, M. (2014). The connection between efficiency and sustainability - a theoretical approach. Procedia Economics and Finance; 15, 1355- 1363.

Brundtland, G.H., (1987). Report of the World Commission on Environment and Development: Our Common Future. Oxford University Press, New York, United Nations, pp. 247. 
Cochran, W. G. (1963). Sampling Techniques, 2nd Ed., New York: John Wiley and Sons, Inc.

Ettah O. I, and Kuye O.O. (2017). Analysis and Determinants of Profit Efficiency of Cassava Farmers in Cross River State, Nigeria. International Journal of Environment, Agriculture and Biotechnology, 2(1), 225-229.

Fadama III Additional Financing report (2019). Retrieved from fadama website on the $3^{\text {rd }}$ of October , 2019 . https://www.fadamaaf.net/.

Girei, A.A., Dire, B., Yuguda, R.M., and Salihu, M. (2014). Analysis of Productivity and Technical Efficiency of Cassava Production in Ardo-Kola and Gassol Local Government Areas of Taraba State, Nigeria. Agriculture, Forestry and Fisheries. 3(1), $1-5$.

Ibeagwa, O.B., Eririogu H., Chikezie C., Ukoha I.I., Osuji M.N., Uhuegbulem I.J. and Barnabas B. C. (2019). Determinants of allocative efficiency of smallholder cassava farmers in Imo State, south east Nigeria The International Journal of Agriculture, Management and Technology, 3(1), 76-83.

International Institute of Tropical Agriculture (IITA), (2019). Information retrieved from its website at: www.iita.org on the $3^{\text {rd }}$ of October, 2019.

Isitor, S.U., Adeyonu, A.G. and Aniegboka, U.N. (2017). An Analysis of Technical Efficiency of Smallholder Cassava Farmers in Anambra State, Nigeria. Applied Tropical Agriculture, 22(2), 10-15.

Itam, K.O., Ajah, E.A., Ofem, U.I., and Abam, O.E. (2015). Technical Efficiency Analysis of Small Scale Cassava Farmers in Cross River State, Nigeria: A Stochastic Production Frontier Approach. Applied Economics and Finance, 2(4), 10-18.

Martin, M. and Taylor, T. G. (2003). A comparison of the efficiency of Producers under collective and individual modes of organization". Colombian Economic Journal, 1(1): 246-266.

Maurice, D. C., Adamu, Y. and Joseph, D. M. (2015). Analysis of cost efficiency in food crop production among small-scale farmers in Adamawa State, Nigeria. Global Journal of Agricultural Sciences, 14, 17-25.

McDonald, J. F. and Moffitt, R. A. (1980). The Uses of Tobit Analysis," The Review of Economics and Statistics, MIT Press, pp 318-321.

Nweke, F.T, Spencer, D.S.C. and lynam, J.K. (2002): Cassava transformation : African's best kept secret. Michigan State University press. Pp. 80- 190. 
Oduntan. O., Amos, T.T. and Oseni, J.O. (2015). Efficiency and Profitability of Small-Scale Cassava Production in Akure Area of Ondo State, Nigeria. Applied Tropical Agriculture; 20(2); 55-61.

Ogunniyi L. T, Ajao A. O, Olapade-Ogunwole F, and Ganiyu M. O. 2012.Resource-use Efficiency of Cassava Production in Atakunmosa Local Government Area of Osun State. Prime Journal of Social Science, 1(2), 27-30.

Ogunniyi, I.T. (2015). Technical, allocative and economic efficiency of cassava producers in Oyo State of Nigeria. Scientia Agriculturae, 11 (2), 53-59.

Ohen, S.B., Ene, D.E. Umeze, G.E. (2014). Resource Use Efficiency of Cassava farmers in Akwa Ibom State, Nigeria. Journal of Biology, Agriculture and Healthcare, 4(2), 126-131.

Oladeebo, J. O. and Oluwaranti, A. S. (2012). Profit efficiency among cassava producers: Empirical evidence from South western Nigeria. Journal of Agricultural Economics and Development, 1(2), 46-52.

Partnership Initiatives in the Niger Delta (PIND) (2011). A Report on Cassava Value Chain Analysis in the Niger Delta. Retrieved from https://pindfoundation.org on the $25^{\text {th }}$ of April, 2019.

Sanginga, N. (2015). Root and Tuber Crops (Cassava, Yam, Potato and Sweet Potato). A publication of the IITA, Ibadan. Retrieved from the https://hdl.handle.net/10568/97416 on the 25th of April 2019.

Simpa, J.O., Nmadu, J.N. and Okino, A. (2014). Technical Efficiency of Smallholder Cassava Farmers in Selected Local Government Areas In Kogi State, Nigeria. Production Agriculture and Technology (PAT) Journal, 10(1), 74-92.

Taiwo, O., , Dayo, O.S., and Bolariwa K.O. (2014). Technical Efficiency Analysis of Cassava Production in Nigeria; Implication for Increased Productivity and Competitiveness. Research Journal of Agriculture and Environmental Management, 3(11), 569-576.

Udoh, E.J., Akpan, S.B. and Edidiong, R.E. (2011). Economic Analysis of Land Allocation Use and Intensification among Arable Crop Farmers in Uruan Local Government Area of Akwa-lbom State, Nigeria. Journal of Economics and Sustainable Development, 2, (11\&12), 1-10

Yusuf T.M., and Adenegan K.O. (2015). Technical efficiency among women farmers in Kwara state: data envelopment analysis approach. Agrosearch; 10(1\&2), 31 - 45. 